DOI: 10.1590/0103-0582201432218713

\title{
Pediatrician's knowledge on the management of the infant who cries excessively in the first months of life
}

\section{Conhecimentos do pediatra sobre o manejo do lactente que chora excessivamente nos primeiros meses de vida}

Actitud, práctica y conocimiento del pediatra sobre el lactante que llora excesivamente durante los primeros meses de vida

Ana Carolina C. Marcon¹, Mário César Vieira , Mauro Batista de Morais²

\section{ABSTRACT}

Objective: To evaluate the attitude, the practice and the knowledge of pediatricians regarding the management of the infant who cries excessively in the first months of life.

Methods: Descriptive cross-sectional study that enrolled pediatricians $(n=132)$ randomly interviewed at a Pediatric meeting in Brazil, in August 2012. The data were collected by a self-administered standardized form after reading the hypothetical case of an infant who cried excessively.

Results: The majority of the participants were females, the mean age was 39 years and the average mean time working in the specialty was 14 years; $52.2 \%$ were Board Certified by the Brazilian Society of Pediatrics. The diagnosis most often considered was gastroesophageal reflux disease (62.9\%), followed by infant colic (23.5\%) and cow's milk allergy (6.8\%). The diagnostic test most frequently mentioned was 24-hour esophageal $\mathrm{pH}$-monitoring (21.9\%). The medications most frequently indicated were domperidone $(30.3 \%)$, the combination of domperidone with ranitidine (12.1\%) and paracetamol (6\%).

Conclusions: In the approach of the infant who cries excessively, diagnostic tests are frequently requested and unnecessary medical treatment is usually recommended.

Key-words: crying; infant; health education.

\section{RESUMO}

Objetivo: Avaliar a atitude, a prática e o conhecimento de pediatras sobre o manejo do lactente que chora excessivamente nos primeiros meses de vida.

Métodos: Estudo transversal descritivo, do qual participaram pediatras ( $\mathrm{n}=132$ ), entrevistados aleatoriamente em evento destinado a especialidade em agosto de 2012. Coletaram-se os dados em uma ficha padronizada e autoadministrada após a leitura do caso hipotético de um lactente que chorava excessivamente.

Resultados: Observou-se maior proporção de pediatras do sexo feminino, média de idade de 39 anos e tempo de formação profissional médio de 14 anos, sendo que 52,2\% eram portadores do título de especialista pela Sociedade Brasileira de Pediatra. A hipótese diagnóstica mais frequentemente considerada foi doença do refluxo gastroesofágico $(62,9 \%)$, seguida por cólica do lactente $(23,5 \%)$ e alergia à proteína do leite de vaca $(6,8 \%)$. O exame complementar mais frequentemente indicado foi a $\mathrm{pH}$-metria esofagiana de 24 horas $(21,9 \%)$. As medicações indicadas com maior frequência foram domperidona em $30,3 \%$, combinação de domperidona com ranitidina $(12,1 \%)$ e paracetamol $(6 \%)$.

Conclusões: $\mathrm{Na}$ abordagem do lactente que chora excessivamente, solicitam-se frequentemente exames complementares e prescrevem-se medicamentos desnecessários.

Palavras-chave: choro; lactente; educação em saúde.
Instituição: Hospital Pequeno Príncipe, Curitiba, PR, Brasil

${ }^{1}$ Hospital Pequeno Príncipe, Curitiba, PR, Brasil

${ }^{2}$ Escola Paulista de Medicina da Universidade Federal de São Paulo (Unifesp), São Paulo, SP, Brasil

\author{
Endereço para correspondência: \\ Ana Carolina C. Marcon \\ Rua Desembargador Motta, 1.890 \\ CEP 80420-190 - Curitiba/PR \\ E-mail: anacarolinamarcon@hotmail.com \\ Conflito de interesse: nada a declarar
}

Aprovado em: 23/1/2014 


\section{RESUMEN}

Objetivo: Evaluar la actitud, la práctica y el conocimiento de pediatras sobre el manejo del lactante que llora excesivamente durante los primeros meses de vida.

Métodos: Estudio transversal descriptivo, del que participaron pediatras $(n=132)$, entrevistados aleatoriamente en evento destinado a la especialidad en agosto de 2012. Se recogieron los datos en una ficha estandarizada y autoadministrada después de la lectura del caso hipotético de un lactante que lloraba excesivamente.

Resultados: Se observó mayor proporción de pediatras del sexo femenino, promedio de edad de 39 años y tiempo de formación profesional mediano de 14 años, siendo que el $52,2 \%$ eran portadores del título de especialista por la Sociedad Brasileña de Pediatría. La hipótesis diagnóstica más frecuentemente considerada fue enfermedad del reflujo gastroesofágico $(62,9 \%)$, seguida por cólicos del lactante $(23,5 \%)$ y alergia a la proteína de la leche vacuna $(6,8 \%)$. El examen complementar más frecuentemente indicado fue la $\mathrm{pH}$-metría esofagiana de 24 horas $(21,9 \%)$. Los medicamentos indicados con mayor frecuencia fueron domperidona en 30,3\%, combinación de domperidona con ranitidina $(12,1 \%)$ y paracetamol $(6 \%)$.

Conclusiones: En el abordaje del tratamiento del lactante que llora excesivamente, se solicitan frecuentemente exámenes complementarios y se prescriben medicamentos innecesarios.

Palabras clave: lloro; lactante; educación en salud.

\section{Introduction}

Newborn crying is a simple behavior, but which involves vast complexity. In the last decades, there were innumerable studies to determine its characteristics, as well as factors associated to its possible etiologies ${ }^{(1)}$.

Excessive crying, given the inherent concern caused in parents, is one of the most frequent reasons of consultation in the first months of life, occurring in 9 to $30 \%$ of infants aged lower than 4 months ${ }^{(1-4)}$. The prevalence may vary according to the definition used ${ }^{(1,4)}$.

This phenomenon is usually transitory and is part of the neurologic development, so most infants present episodes of inconsolable crying in the first months life.

According to longitudinal studies, in $5 \%$ of infants, crying persists up to 5 months of age ${ }^{(5)}$. The objective of this study was to analyze how pediatricians interpret excessive crying in infants in the first months of life, as well as its respective management, due to the importance of this clinical condition in routine pediatric practice.

\section{Method}

Descriptive cross-sectional study involving a convenience sample consisting of 132 pediatricians randomly included and attendees of a nationwide event on Pediatrics (69 Curso Nestlé), performed in the municipality of Rio de Janeiro in August, 2012.

The study included pediatric residents, pediatricians with or without a specific pediatric specialty, and general practitioners who were Board Certified by the Brazilian Society of Pediatrics.

The instrument used for data collection was a standard professional form, which consisted of an initial piece of identification information on sex, age, country of residence, time since graduation in Medical School, degree of specialization in Pediatrics and place of professional practice (clinic, hospital, university and/or public service). The second part consisted of questions regarding the clinical scenario: "twomonth-old infant, female, under exclusive breastfeeding, previously healthy, without intercurrences in the neonatal period comes to the pediatrician with maternal complaints of daily excessive crying. Refers the symptoms especially at night with more than 4 hours of progression in the last 3 weeks of life. Presented frequent regurgitations during the day after feedings. The physical examination was appropriate, as well as weight gain and psychomotor development ( $40 \mathrm{~g} /$ day)". After reading the case, the following open questions were presented, without alternatives for the answers. Each professional answered freely.

1. Which is the most likely diagnosis in the above case?

2. Would you require an additional exam to better clarify the case? If so, which one?

3. What would be the initial management of this patient?

All 132 forms were returned and fully answered. The answers were interpreted individually, extracting the information, which were included in a spreadsheet. The data, graphs, and tables were generated and analyzed in Microsoft Excel $^{\circledR} 2007$.

The study was approved by the Research Ethics Committee of Hospital Pequeno Príncipe in the municipality of Curitiba, state of Paraná, and the informed consent was obtained from all participants. 
Table 1 - General characteristics of the 132 physicians interviewed

\begin{tabular}{|c|c|c|}
\hline & Category & n (\%) \\
\hline \multirow{2}{*}{ Sex } & Female & $97(73.5)$ \\
\hline & Male & $35(26.5)$ \\
\hline \multirow{5}{*}{ Regions of Brazil } & Southeast & $69(52.2)$ \\
\hline & South & $32(24.4)$ \\
\hline & Northeast & $13(9.8)$ \\
\hline & Midwest & $9(6.8)$ \\
\hline & North & $9(6.8)$ \\
\hline \multirow{6}{*}{ Education } & Residency in Pediatrics and TSP & $46(34.8)$ \\
\hline & Residency in Pediatrics without TSP & $43(32.6)$ \\
\hline & Residency in Pediatrics, TSP and pediatric specialty & $20(15.1)$ \\
\hline & Resident Doctor in Pediatrics (1st year) & $13(9.9)$ \\
\hline & Resident Doctor in Pediatrics (2nd year) & $7(5.3)$ \\
\hline & Residency in other areas and TSP & $3(2.3)$ \\
\hline \multirow{8}{*}{ Place of professional practice } & Clinic (private sector) + Hospital (public sector) & $60(45.4)$ \\
\hline & Primary Care (public sector) & $25(19.0)$ \\
\hline & Clinic (private sector) & $24(18.2)$ \\
\hline & Hospital (private sector) & $10(7.6)$ \\
\hline & Clinic + primary care (public sector) & $8(6.0)$ \\
\hline & Hospital (private sector) + primary care (public sector) & $3(2.3)$ \\
\hline & Hospital (public sector) + Professor & $1(0.7)$ \\
\hline & Office (private sector) + Professor & $1(0.7)$ \\
\hline
\end{tabular}

TSP: Title of Specialist - Board Certified by the Brazilian Society of Pediatrics/Brazilian Medical Association

\section{Results}

The general characteristics of the studied population are presented in Table 1. All questionnaires were randomly distributed, which were returned soon after. There was a greater proportion of female pediatricians. Age ranged from 24 to 65 years (mean of 39 years). The time since graduation in Medical School ranged from zero to 37 years (mean of 14 years). Most participants concluded their training in a pediatric residency program and more than half (52.2\%) were Board Certified by the Brazilian Society of Pediatrics. Among the interviewees, 112 (85\%) did not have a certificate in a specific field of action. Most interviewees (52.2\%) lived in the Southeast region of Brazil and $53.7 \%$ worked both in the private sector and in the public sector.

The information on diagnosis, the exam that would be requested, and the management were retrieved from the written answers to the three formulated questions. The three answers were identified on the 132 forms collected.

The diagnostic hypotheses proposed by the respondents are presented in Table 2. Gastroesophageal reflux disease (GERD), followed by infant colic, cow's milk protein allergy (CMPA), and absence of sickness (healthiness) were the most cited diagnosis by physicians.
Table 2 - Diagnostic hypotheses established by the 132 physicians surveyed

\begin{tabular}{lc}
\hline Diagnoses & $\mathbf{n}(\%)$ \\
\hline Gastroesophageal reflux disease & $83(62.9)$ \\
Infant colic & $31(23.5)$ \\
Cow's Milk Protein Allergy & $9(6.8)$ \\
Healthiness & $7(5.3)$ \\
Acute gastroenteritis & $2(1.5)$ \\
\hline
\end{tabular}

As to the need for exams to investigate the case, $37.8 \%$ of respondents requested an additional exam, and the 24-hour esophageal pH-monitoring was the most cited exam, followed by contrast radiography of the esophagus, stomach, and duodenum (ESD), abdomen ultrasound, upper gastrointestinal endoscopy (UGI), and measurement of Specific IgE against cow's milk (Table 3 ).

The treatment modalities suggested by pediatricians were associated to the diagnosis proposed and are presented in Table 4. Only 20 (15\%) physicians did not indicate some therapeutic modality for the management of the reported clinical condition. Among the interviewed physicians, only 
three $(2.2 \%)$ cited the instruction of parents about the normalcy of the symptoms as a treatment option.

When clinical diagnosis was GERD (62.9\%), 47 (56.6\%) physicians requested additional medical examination (Table3) and $58(70 \%)$ indicated some pharmacological treatment of the case, as shown in Table 4.
Infant colic was suspected in $31(23.5 \%)$ interviewees and most participants did not request any further exam to complement diagnostic elucidation. However, 19 (61.2\%) would indicate some kind of pharmacological treatment, and dimethicone and paracetamol were the medications chosen by these pediatricians to control the symptoms presented by the infant.

Table 3 - Additional exams requested by the 132 physicians interviewed

\begin{tabular}{|c|c|c|}
\hline & Requested exams & n (\%)* \\
\hline \multirow{5}{*}{ Gastroesophageal Reflux Disease } & None & $36(43.4)$ \\
\hline & $\mathrm{pH}$-monitoring & $29(35.0)$ \\
\hline & contrast radiography ESD & $9(10.8)$ \\
\hline & Abdominal ultrasonography & $7(8.4)$ \\
\hline & Upper Digestive Endoscopy & $2(2.4)$ \\
\hline Infant colic & None & $30(96.8)$ \\
\hline \multirow{2}{*}{ Cow's Milk Protein Allergy } & None & $7(77.8)$ \\
\hline & Specific IgE against cow's milk & $2(22.2)$ \\
\hline Healthiness & None & $7(100)$ \\
\hline Acute gastroenteritis & None & $2(100)$ \\
\hline
\end{tabular}

*Percentage refers to the proportion of diagnostic tests requested per diagnosis

Table 4 - Proposed diagnosis established by the 132 interviewed doctors

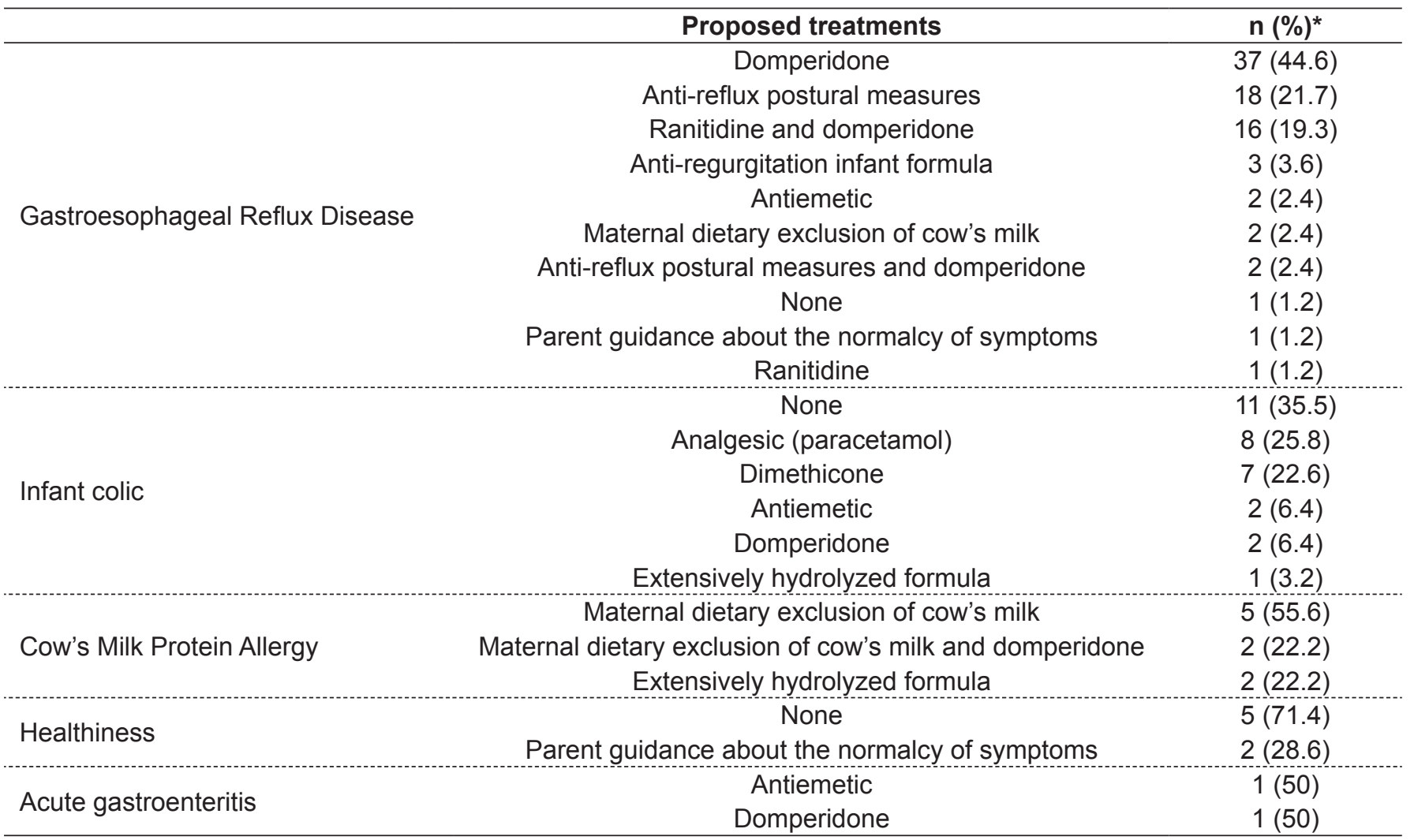

*Percentage refers to the proportion of the number of treatments suggested per diagnosis 


\section{Discussion}

Traditionally, excessive crying is defined as a case in which the infant presents irritability, crying and/or agitation for more than 3 hours a day in more than 3 days a week ${ }^{(6)}$. Crying in the first months of life is also contemplated in the Rome III classification as a functional gastrointestinal entity denominated infant colic, practically with the same criteria established by Wessel in the $1950 \mathrm{~s}^{(6,7)}$. However, there are more subjective definitions when there is maternal observation that the infant is crying or is inconsolable ${ }^{(4)}$.

Despite the indefinite etiology, some factors have already been implicated, such as: the infant's temperament ${ }^{(8)}$, neurological maturity related to delayed development and maturation of the parasympathetic nervous system, the transition of sleep-wake cycle ${ }^{(8)}$, the poor performance in prenatal care ${ }^{(1)}$ and even cultural organic diseases ${ }^{(1,2,4,9)}$. It is important to mention that only in 5\% of cases an underlying organic disease $^{(1)}$ was identified, and, in such cases, normally other factors were associated, such as poor weight gain, changes in the feces and/or developmental delay ${ }^{(5)}$

Currently, the most accepted theory is that healthy infants signal the need for a response from their caregiver by changing breathing patterns, color and/or posture variation, manifested by patterns of movement and vocalization of a cry and/or crying, these latter being the highest concerns of caregivers ${ }^{(5)}$. The intensity of the behavior may depend on temperament, neurodevelopmental maturity, ability to adapt to the environment, or unknown factors ${ }^{(5)}$.

Even when considered excessive, crying is a benign entity in most cases, but can lead to short- and long-term consequences, such as early termination of breastfeeding, early introduction of solid foods, frequent change of infant formula, maternal irritability and frustration, reduction of mother-infant interaction, increased risk of physical abuse, behavioral disorders at pre-school age, hyperactivity, and sleep disorders ${ }^{(8)}$.

In addition to the aforementioned consequences, this clinical condition is often confused with gastrointestinal disorders, such as GERD, and the infant is subjected to unnecessary investigations and potential pharmacological treatments. In this study, GERD was suspected for the majority of respondents $(62.9 \%)$ and the 24-hour esophageal $\mathrm{pH}$-monitoring was the most requested exam (43\%) for diagnostic testing. Despite belonging to the diagnostic arsenal of GERD, this is a valid exam, especially to assess the antisecretory therapy and to investigate atypical manifestations of the disease $e^{(9)}$, absent in the clinical case described. Irritability will only be present in a child with GERD if he or she has esophagitis, which is rare in the age range mentioned, and in such cases, upper gastrointestinal endoscopy is the most accurate test to evaluate the esophageal mucosa ${ }^{(9,10)}$.

Although two international consensuses by committees of experts agree that GERD is not a cause of irritability and/or inconsolable crying in the first month of life, many pediatricians attribute a relation between these different situations ${ }^{(9,10)}$. Several studies have demonstrated that the use of acid inhibitors does not lead to the improvement of symptoms in infants with these clinical manifestations ${ }^{(11,12)}$. Furthermore, in recent years, it is noted in medical practice the excessive use of proton pump inhibitors (PPIs) to treat or alleviate intense crying in healthy term children, without signs or symptoms indicating an organic disease. These drugs are not recommended for a child whose only problem is excessive crying, even if it is associated to arching back and refusal to feed ${ }^{(5,11-15)}$. In children with documented GERD, the PPIs have proven effective in reducing acid exposure, but are not able to improve irritability ${ }^{(12-14)}$. Despite the lack of evidence to support its use in the treatment of GERD symptoms in children, PPIs were prescribed to 145 thousand children under 12 months, in 2009, in the United States ${ }^{(15)}$. The use of this medication should be reserved for the treatment of acid-induced lesions, documented by upper endoscopy ${ }^{(13,15)}$. In this study, the interviewed physicians did not mention this medication.

Just as in the crying, the regurgitation and vomiting were common physiological phenomena in children in the first months of life, reaching a maximum of 3 to 4 months of age and, when associated, despite not having a causal relationship, increase the chances of a healthy infant getting at least one medication characterized as anti-reflux ${ }^{(13,16,17)}$. In this study, great part of the interviewed physicians attributed an organic etiology to the excessive crying of an infant with regurgitation, without characteristics of organic disease, adding additional exams and pharmacological treatment for the management of the case. It should be noted that a significant number of pediatricians prescribed domperidone and ranitidine, including combined, for the management of the chief complaint, crying.

The key-question for the pediatrician is to distinguish the clinical manifestations of physiological gastroesophageal reflux (GER) from GERD, to identify the patients who need investigation and/or treatment ${ }^{(18)}$. The clinical history and physical examination, with attention to warning signs, are 
usually sufficient to allow the clinician to establish the difference ${ }^{(19)}$. Parental guidance and clarification are essential ${ }^{(19)}$. The spontaneous resolution of GER is common and the evolution is generally benign, with low incidence of complications $^{(18,20)}$. Around $70-85 \%$ of children have regurgitations in the fist 2 months of life and it resolves without intervention in $95 \%$ of children until 1 year of age ${ }^{(20)}$. Therefore, the prolonged or repeated use of pharmacological therapy should not be prescribed before diagnostic confirmation, especially in infants ${ }^{(18)}$.

It is crucial that pediatricians learn to recognize situations that are considered physiological to minimize unnecessary additional investigations as well as to decrease the anxiety of parents, explaining the benignity of the condition.

The results of this study allow us to conclude that the respondents demonstrated inadequacy in addressing the child that cries excessively in the first months of life, as well as in the investigation and management of gastrointestinal conditions in childhood, such as GERD and CMPA.

Excessive crying in infants demand attention by pediatricians and longer outpatient visits. However, non-pharmacological guidelines given by an experienced professional regarding breastfeeding, as well as information about the absence of organic disease, have good results ${ }^{(16,17)}$. The doctor should also pay attention to maternal mental health and the repercussions of this situation on the family context ${ }^{(17)}$.

Considering that the sample evaluated in this investigation was gathered in a pediatric update event, and understanding that professionals that seek these activities are usually more interested in continuing education programs, the results cannot be generalized to the whole population of pediatricians. It is possible that samples including physicians who do not attend continuing education activities may reveal a number of unsubstantiated practices for infant crying, which may be a step within normal development.

These data emphasize the need for the development of educational strategies to enhance the knowledge of these professionals, in order to avoid excessive additional investigations and the prescription of medications with potential adverse effects and no benefits in the natural evolution of the crying infant.

\section{References}

1. Branco AS, Fernandes A, Garcia FT, Gouveia R. Primary excessive crying in infants. Acta Pediatr Port 2002;33:189-96.

2. St James-Roberts I, Bowyer J, Varghese S, Sawdon J. Infant crying patterns in Manali and London. Child Care Health Dev 1994;20:323-37.

3. Michelsson K, Rinne A, Paajanen S. Crying, feeding and sleeping patterns in 1 to 12-month-old infants. Child Care Health Dev 1990;16:99-111.

4. van den Boom DC, Pauw-Plomp H, de Jonge GA. Mothers' reports of infant crying and soothing in a multicultural population. Arch Dis Child 1998;79:312-7.

5. Barr RG, Kramer MS, Pless IB, Boisjoly C, Leduc D. Feeding and temperament as determinants of early crying/fussing behavior. Pediatrics 1989;84:514-21.

6. Wessel MA, Cobb JC, Jackson EB, Harris GS Jr, Detwiler AC. Paroxysmal fussing in infancy, sometimes called colic. Pediatrics 1954;14:421-35.

7. Tack J, Talley NJ, Camilleri M, Holtmann G, Hu P, Malagelada JR et al. Functional gastroduodenal disorders. Gastroenterology 2006;130:1466-79.

8. Baildam EM, Hillier VF, Ward BS, Bannister RP, Bamford FN, Moore WM. Duration and pattern of crying in the first year of life. Dev Med Child Neurol 1995;37:345-53.

9. Vandenplas Y, Rudolph CD, Di Lorenzo C, Hassall E, Liptak G, Mazur $\mathrm{L}$ et al. Pediatric gastroesophageal reflux clinical practice guidelines: joint recommendations of the North American Society for Pediatric Gastroenterology, Hepatology, and Nutrition (NASPGHAN) and the European Society for Pediatric Gastroenterology, Hepatology, and Nutrition (ESPGHAN). J Pediatr Gastroenterol Nutr 2009;49:498-547.

10. Rudolph CD, Mazur LJ, Liptak GS, Baker RD, Boyle JT, Colletti RB et al. Guidelines for evaluation and treatment of gastroesophageal reflux in infants and children: recommendations of the North American Society for Pediatric Gastroenterology and Nutrition. J Pediatr Gastroenterol Nutr 2001;32 (Suppl 2):S1-31.
11. Jordan B, Heine RG, Meehan M, Catto-Smith AG, Lubitz L. Effect of antireflux medication, placebo and infant mental health intervention on persistent crying: a randomized clinical trial. J Paediatr Child Health 2006;42:49-58.

12. Orenstein SR, Hassall E, Furmaga-Jablonska W, Atkinson S, Raanan M. Multicenter, double-blind, randomized, placebo-controlled trial assessing the efficacy and safety of proton pump inhibitor lansoprazole in infants with symptoms of gastroesophageal reflux disease. J Pediatr 2009;154:514-20.

13. Putnam PE. Stop the PPI Express: they don't keep babies quiet! J Pediatr 2009;54:475-6.

14. Moore DJ, Tao BS, Lines DR, Hirte C, Heddle ML, Davidson GP. Double-blind plabebo-controlled trial of omeprazole in irritable infants with gastroesophageal reflux. J Pediatr 2003;143:219-23.

15. Chen IL, Gao WY, Johnson AP, Niak A, Troiani J, Korvick J et al. Proton pump inhibitor use in infants: FDA reviewer experience. J Pediatr Gastroenterol Nutr 2012;54:8-14.

16. Douglas $P$, Hill P. Managing infants who cry excessively in the first few months of life. BMJ 2011;343:d7772.

17. Putnam PE. GERD and crying: cause and effect or unhappy coexistence? J Pediatr 2002;140:3-4.

18. Ferreira CT, Carvalho E, Sdepanian VL, Morais MB, Vieira MC, Silva LR. Gastroesophageal reflux disease: exaggerations, evidence and clinical practice. J Pediatr (Rio J) 2014;90:105-18.

19. Lightdale JR, Gremse DA; Section on Gastroenterology, Hepatology, and Nutrition. Gastroesophageal reflux: management guidance for the pediatrician. Pediatrics 2013;131:1684-95.

20. Czinn SJ, Blanchard S. Gastroesophageal reflux disease in neonates and infants: when and how to treat. Paediatr Drugs 2013;15:19-27. 